\title{
PRIVATISATION AND PUBLIC OWNERSHIP IN FINLAND
}

\author{
JOHAN WILLNER
}

\author{
CESIFO WORKING PAPER NO. 1012 \\ CATEGORY 9: INDUSTRIAL ORGANISATION \\ August 2003
}

Presented At CESifo CONFERENCE on PRIVATISATION EXPERIENCES IN EU, JANUARY 2003

\author{
An electronic version of the paper may be downloaded \\ - from the SSRN website: Www.SSRN.com \\ - from the CESifo website: www.CESifo.de
}




\title{
PRIVATISATION AND PUBLIC OWNERSHIP IN FINLAND
}

\begin{abstract}
Finland's state-enterprise sector has been larger than in most countries and included several manufacturing companies. These were usually established because of a scarcity of private venture capital, with a mission to contribute to industrialisation. Some companies have now been privatised in a process that has been fairly successful in its stated aims of generating revenues and achieving industrial restructuring. But the state-owned companies have also been fairly successful, so there is no evidence of improved financial performance or cost efficiency despite stronger focus on profits. Costs have on the other hand often been reduced in traditional public-sector industries, where private provision has increased with deregulation and/or competitive tendering and more commercial objectives. The consequences for allocative efficiency are however ambiguous, because of changes in quality and working conditions.
\end{abstract}

JEL Code: L32, L33, H42.

Keywords: privatisation, public ownership, Finland.

\author{
Johan Willner \\ Department of Economics and Statistics \\ Abo Akademi University \\ Fänriksgatan $3 B$ \\ FIN-20500 Turku/Åbo \\ Finland \\ jwillner@abo.fi
}

This version has benefited from comments to the first draft by participants in the CESifo seminar Privatisation Experiences in the EU, Munich, 10-11.1.2003. Discussions with my colleagues Jan Otto Andersson and Tom Björkroth have also been helpful. Markku Tapio (Department for Trade and Industry, Finland), Kaarina Wulff (Engel Group) and Matti Mertsola (MB Funds) have kindly answered my questions. Discussions with a couple of former public and private sector managers have also been helpful. However, I am solely responsible for remaining errors and misunderstandings. 


\section{Introduction}

As in most other European countries, public ownership in Finland has dominated infrastructure industries and public services, but has been present in manufacturing and banking as well. State-ownership amounted to $18-22 \%$ of industrial value added, $12-15 \%$ of industrial employment and 23-30\% of the export, before the privatisation wave. Ignoring definitional problems, this can be compared to shares of value added such as $13.9 \%$ in Austria, $10.5 \%$ in Britain, $7.1 \%$ in Germany, $6 \%$ in Sweden and 1-2\% in the US (Bureaucrats in Business: 263-264; contributions in Parker, 1998).

Finland has no privatisation programme. Each company is treated individually but the government distinguishes between three main groups (Kaisanlahti, 2001; Government Decision on the State's Corporate Ownership Policies, 2001; Omistuspohjan laajentaminen, 2002). The first group is associated with wider objectives ('special assignments') and will remain in public control, despite some partial privatisation. Energy, air transport and the retail trade of alcohol have special assignments, like broadcasting, lotteries and football pools. The second group, which includes chemicals and basic metals and associated technology, is seen as being of strategic importance. The state will remain a shareholder, but ownership may be reduced below 50\%. The third group, which includes paper, metal engineering, and banking, consists of investment objects that may be divested if necessary.

Privatisation in manufacturing and banking has often been associated with mergers and hence a reduced number of domestic producers. This stands in contrast to public services and some infrastructure industries, where increased private provision is often a byproduct of increased competition. So far, privatisation of natural monopolies is not on the agenda, so there are usually no British-style regulatory bodies.

I shall follow the Ministry of Trade and Industry in Finland in defining a company of which the state owns at least $50 \%$ as state-owned and a company with a lower proportion (and no government-appointed supervisory board) as associated (Kaisanlahti, 2001: 57). Privatisation will be defined as lost majority ownership. Next section highlights the reasons for the strong position of public ownership in Finland, section 3 the privatisation process and section 4 its motives. Sections 5 and 6 ask whether the aims of public ownership and privatisation have been met. Section 7 deals with profitability and cost efficiency, and section 8 with other aspects of social welfare. Section 9 discusses lessons to be learned.

\section{Public ownership and its objectives}

A natural monopoly is in general either nationalised or at least regulated so as to avoid excessive prices, but public ownership in a mixed oligopoly can also under some circumstances be beneficial by reducing profit margins throughout an industry (Cremér et al., 1989; 
De Fraja and Delbono, 1989; Willner, 1999). Other market failures, such as external costs and benefits, have also been used as a motive for public ownership. Quality can for example be distorted (Spence, 1975), not least because of cost-cutting related to objectives that are difficult to monitor (Holmström and Milgrom, 1991).

Public ownership can also be a substitute when capital markets are underdeveloped, or investors too short-termist or risk-averse (Rees, 1984). This was the case in Finland, where companies tended to be created (often by non-socialist governments) rather than nationalised (Miettinen, 2000; Pohjola, 1996). However, they often had a comparative advantage in expanding to sectors where public ownership was not the only alternative (Aura, 1962a). Similar methods have to some extent been used also in countries such as Germany, Ireland, Sweden and even the US (contributions in Parker, 1998; Hausman and Neufeld, 1999).

Industrialisation was also affected through selective promotion of industries, tax exemptions, subsidies, and a procyclical fiscal policy that was seen as causing a succession of growth and consolidation (Pekkarinen and Vartiainen, 2001). Moreover, firms were able to borrow from the central bank, partly so as to force other banks to reduce their interest margins (Knoellinger, 1935: 327), as an example of a mixed-oligopoly strategy.

The state was in other words concerned with providing access to credit, but presentstyle financial markets were hardly thinkable, not least because foreign takeovers were unwelcome. Higher social than private returns on investments and slow enterprise formation despite good profit opportunities might also explain why state-ownership was included among the growth strategies (Miettinen, 2000; see also Geroski, 1995). Another motive was to reduce the dominance over the business community by the then powerful Swedish-speaking minority (Pohjola 1996: 33). Such dominance over strategic decisions by a subset of those affected would not be desirable (see also Cowling and Sugden, 1998).

A growing wage share was after the war believed to jeopardise investments and hence growth, but to restrain wages in favour of the 20 wealthiest families was seen as neither desirable nor politically feasible. Increased state-ownership was believed to make the unions accept wage moderation, and not to lead to high wages as is now often believed.

Nationalisation was ruled out for ideological and practical reasons, so investments had to be directed towards new and existing state-owned companies (Kekkonen, 1952: 73-96). ${ }^{1}$

\footnotetext{
${ }^{1}$ The author of the blueprint in question, Urho Kekkonen, was several times prime minister and was later to become president (1956-81).
} 
A developmental motive for state-ownership was present in the forest industry (Enso-Gutzeit and Veitsiluoto), mining (Outokumpu), and fertilisers and other chemicals (Rikkihappo and Typpi, later merged as Kemira). There was state-ownership also in banking (the postal savings bank Postisäästöpankki), and in wines and spirits (although with a different motive). Companies that were established after the war produced transport equipment (Valmet and Vanaja), steel (Rautaruukki), oil products (Neste), paper machines (Valmet) and cars (the joint venture Saab-Valmet). Their emphasis has in many cases now shifted from manufacture to technology (see section 5). State-enterprises were usually organised as limited companies so as to be more flexible than in the public sector and independent from the statebudget, in contrast to for example Britain and Ireland.

Finland is now industrialised, but ownership can still matter if objectives differ. However, most firms and in particular those that were state-owned became more oriented towards profitability and shareholder-value in the 90s. State-owned firms also become more oriented towards customers and less towards technological development (Miettinen, 2000).

However, state-owned firms were more growth-oriented as late as 1986-89 (Miettinen, 2000). This probably meant higher output than otherwise, and hence somewhat lower prices throughout the industry, as in a mixed oligopoly. Also, public firms were supposed to take social welfare, public service and the environment into consideration, despite an emphasis on profits (Aura, 1962a, 1962b; Miettinen, 2000), and they sometimes supported private firms at the expense of heir own profitability through low prices on energy or freight services. The state is in addition less prejudiced, because $25 \%$ (and probably $40 \%$ in the near future) of the board members of its listed companies are female, as compared to $7 \%$ among private plc:s (Hufvudstadsbladet, 9.12.2002; Valtionyhtiöiden hallituksiin löytyy päteviä naisia, 2003).

\section{Industries affected by privatisation}

Despite a stronger market orientation, privatisation was still seen as an extremely right-wing idea in Finland in the 80s. However, to sell state-enterprises appeared on the agenda through a government blueprint in 1991, when the left was still in government. Next government was right-wing and favoured privatisation, but was prevented until 1994 because of the recession. The policy was continued 1995-2003 by the broad coalition that ruled after a swing to the left. The present centre-left government (2003-) however wants the state to remain a big owner, without ruling out some divestiture (Ajankohtainen näkemys, 2003). 
Some state-owned companies were sold before the 90 s, as part of a pragmatic policy allowing for acquisitions as well. But the privatisations from 1994 onwards signify a policy shift. There are now 31 companies left with more than 50\% of state-ownership, and 18 associated companies. The most important privatised companies are Enso (1998), Sisu (1997), Valmet (1996), Rautaruukki (1997) and the former postal savings bank Leonia (2000). ${ }^{2}$ The state owns less than 50\% in Outokumpu as well since 1994, but shares owned by a publicsector organisation mean that Outokumpu is still a public firm (like Rautaruukki until 1998). Table I presents the most important cases of privatisation and remaining public ownership, including predecessors when relevant (below the main row for each company).

Table I. Privatisation and remaining public ownership: banking and manufacturing ${ }^{\mathrm{a}}$

\section{Company}

Alko-Yhtiöt (alc. beverages, prod. and trade) ${ }^{\mathrm{b}}$

- Alko Inc (retail trade)

- Altia Group Oy (prod. and wholesale trade)

Fortum Corporation (energy production, oil refining)

- Neste Oy (oil refining)

- Ivo Group (energy production)

Kemijoki Oy (energy production)

Kemira Oy (chemicals) ${ }^{c}$

Kone Oyj (lifts and escalators)

- Partek Corporation (engineering industry)

- Oy Sisu Ab (vehicles, defence equipment, components)

Metso Corporation (metal engineering)

- Valmet Oy (metal engineering)

Outokumpu Oyj (metals and technology) ${ }^{\mathrm{d}}$

Patria Industries Oyj (defence materials and technology)

Rautaruukki Corporation (mining and metals)

Sampo plc (banking and insurance)

- Postipankki Oy (subsequently Leonia Oy; banking)

Stora Enso Oyj (forest industry) ${ }^{\mathrm{e}}$

- Enso Oy

- Enso-Gutzeit Oy

- Veitsiluoto Oy

Vapo Oy (peat, timber, biotechnology)

\begin{tabular}{|c|c|c|c|}
\hline 1990 & 1996 & 2003 & $\begin{array}{l}\text { Minimum } \\
\text { ownership }\end{array}$ \\
\hline \multirow[t]{4}{*}{$100.0 \%$} & $100.0 \%$ & & \\
\hline & & $100.0 \%$ & \\
\hline & & $100.0 \%$ & $50.1 \%$ \\
\hline & & $60.8 \%$ & $50.1 \%$ \\
\hline $98.0 \%$ & $83.6 \%$ & & \\
\hline $95.6 \%$ & $95.6 \%$ & & \\
\hline $77.3 \%$ & $78.2 \%$ & $67.0 \%$ & $51.0 \%$ \\
\hline \multirow[t]{3}{*}{$100 \%$} & $72.3 \%$ & $56.2 \%$ & $15.0 \%$ \\
\hline & & $4.7 \%$ & $0.0 \%$ \\
\hline & $30.2 \%$ & & \\
\hline \multicolumn{4}{|l|}{$97.7 \%$} \\
\hline & & $11.5 \%$ & $0.0 \%$ \\
\hline $79.8 \%$ & $20.3 \%$ & & \\
\hline \multirow[t]{2}{*}{$57.5 \%$} & $40.0 \%$ & $39.6 \%$ & $10.0 \%$ \\
\hline & .. & $73.2 \%$ & $50.1 \%$ \\
\hline \multirow[t]{2}{*}{$86.8 \%$} & $68.9 \%$ & $40.1 \%$ & $20.0 \%$ \\
\hline & & $40.4 \%$ & $0.0 \%$ \\
\hline \multirow[t]{3}{*}{$100.0 \%$} & $100.0 \%$ & & \\
\hline & & $11.2 \%$ & $0.0 \%$ \\
\hline & $35.2 \%$ & & \\
\hline $\begin{array}{l}50.3 \% \\
88.8 \%\end{array}$ & & & \\
\hline $100.0 \%$ & $100.0 \%$ & $66.7 \%$ & $50.1 \%$ \\
\hline
\end{tabular}

a) Sources: State Owned and Associated Companies, annual reports for 1990, 1995, 2001 and 2002; and (2003). b) The subsidiary Arctia (hotels and restaurants) now belongs to the Scandic chain. c) A failed privatisation attempt was made in 2002. d) The Finnish Social Insurance Institution owns $12.3 \%$ of the shares, so the majority of the shares are still directly or indirectly in public ownership. e) Enso was still indirectly in public ownership 1996 through The Finnish Social Insurance Institution until being merged with Stora Ab in Sweden in 1998.

${ }^{2}$ The process has also included temporary nationalisation, as Keskometalli and Fundia were merged with Rautaruukki before 1998. Also, selling Sisu to the transport equipment manufacturer Partek in return for shares made Partek an associated company (30.4\%), like Kone (4.7\%) after its acquisition of Partek in 2002. 
Industries like telecommunications, railways and the postal services were earlier part of the public administration and directly dependent of the state budget, but are now reorganised as limited companies in the same way as in manufacturing. Public ownership is likely to dominate in electricity, railways and postal services, but private provision may increase through deregulation and competition. ${ }^{3}$ There is not yet competition in rail transport, but commuter routes around Helsinki may become tendered, and private freight-companies may enter. Finland is in fact lobbying the EU in favour of more deregulation.

The electricity grid is state-owned. IVO-group and providers owned by the manufacturing sector used to dominate generating, with the remainder divided between local and often municipal distributors (Lehto, 1997a). Vattenfall in Sweden has now taken over some distribution, but state-ownership still dominates. Telecom Finland was separated from the PT-administration and subsequently listed as Sonera. Pioneering deregulation in the early 90s caused domination by Sonera, a group of former local not-for-profit providers (Finnet-yhtiöt), and Sweden's former PT-administration (Telia). Telia-Sonera is since 2002 in joint state-ownership with Sweden, but privatisation in the near future is likely. This merger meant a duopoly in fixed long-distance calls, but Telia-Sonera's mobile-call division had to be sold. This industry may no longer be a natural monopoly, but further consolidation may create players that are larger than the former PT-administrations.

State activities such as in-house catering, cleaning and property management have been reorganised and sold. For example, cleaning and maintenance were separated from property management and privatised in 1998 after being transformed to Engel Group Ltd in 1994. Medivire, which is now largest in occupational health-care in Finland and no longer limited to the state-sector, was privatised in 2000. Public ownership and privatisation in this group of industries is summarised in Table II, but energy is included in Table I because of the merger between IVO and Neste.

Universities are state-owned, and primary and secondary schools are in general municipal. There has on the other hand always been some private provision of health-care, and there are now even some specialised private hospitals. The public health-care sector is underfunded, so the use of private services has increased. Existing hospitals are not privatised, but a local hospital faced by closure has been taken over by the voluntary sector.

\footnotetext{
${ }^{3}$ This can also mean international competition between state-owned providers, as in electricity distribution and telecommunications, and even increased public provision, as when a railway subsidiary entered urban bus transport. The Swedish state railways also operated bus services in the Helsinki region for some time.
} 
Table II. Privatisation and remaining public ownership: traditional public-sector industries ${ }^{\mathrm{a}}$

\section{Company}

Engel Group Ltd (property management, cleaning)

- Rakennushallitus (property management, cleaning)

Finland Post Corporation (postal services)

Finnair Oyj (air transport)

Medivire Työterveyspalvelut Oy (occupational health(are) $)^{\mathrm{b}}$

- The state sector's occupational health-care system

Telia-Sonera Corporation (telecommunications) ${ }^{c}$

- Sonera Corporation

- Suomen PT Oy

Oy Veikkaus Ab (football pools and lottery)

VR-group (rail transport)

Oy Yleisradio Ab (broadcasting)

\begin{tabular}{rrr}
1990 & 1996 & \multicolumn{1}{l}{$\mathbf{2 0 0 2}$} \\
& $100 \%$ & $43.0 \%$ \\
$100 \%$ & & \\
$100.0 \%$ & $100.0 \%$ & $100.0 \%$ \\
$70.0 \%$ & $60.9 \%$ & $58.4 \%$ \\
& $100 \%$ & $37.3 \%$ \\
& & \\
$100 \%$ & & \\
& & $19.1 \%$ \\
$100.0 \%$ & $100.0 \%$ & {$[52.8 \%]$} \\
$100.0 \%$ & $100.0 \%$ & $99.6 \%$ \\
$100.0 \%$ & $100.0 \%$ & $100.0 \%$ \\
$99.9 \%$ & $99.9 \%$ & $100.0 \%$
\end{tabular}

Minimum ownership

a) Sources: annual reports (Statsbolagen 1990, 1995, and 2001), Ministry of Trade and Industry press releases (2.8.1996 and 18.9.1996); Valtionyhtiöt ja osakkuusyhtiöt (2002) and (2003); MB Funds lead the acquisition of Medivire (2002) b) The state is now a minority-owner through the investment company Solidium. c) Sonera, with a share of state ownership of $52,8 \%$, is now being merged with the Swedish state-owned operator Telia, where Sonera's share becomes $36 \%$, but further divestiture is to be expected.

As for other local and regional services, suburban bus operators in the Helsinki region were sold to large foreign companies, and private but domestic operators took over routes in Turku because of competitive tendering. Many local authorities have implemented competitive tendering and hence increased private provision also in cleaning, refuse collection and building work, partly because of budgetary problems (Böckerman, 1997). ${ }^{4}$

\section{The motives for privatisation}

Policy-documents in Finland are not always explicit on the motives for privatisation, and there have been few debates on the issue. But the blueprint that introduced privatisation on the agenda described state-owned companies as fairly efficient and emphasised the sales revenues as the most important motive (Visio yksityistämisestä Suomessa, 1991). To maintain competition through a mixed oligopoly was ruled out as unsound. The blueprint recommended mergers rather than increased domestic competition. It also warned against public-sector dominance, which would increase by a merger without privatisation. Subsequent policy-documents also refer to the fact that the mission to industrialise is fulfilled (Kääriäinen, 1994; Valtion yhtiöomistuksen historia, 2001; Willner, 1998; Miettinen, 2000). For example, the 'strategic and socio-political' need to keep Rautaruukki state-owned has been described as no longer valid (Salminen and Viinamäki, 2001).

\footnotetext{
${ }^{4} \mathrm{~A}$ left-wing local administration actually leads to increased private provision, probably because of financial constraints that make increased private provision attractive as a substitute to cuts (Granqvist, 1997).
} 
The authorities also refer to changed business conditions, in particular integration, international competition a need of rapid reaction as motives for privatisation and merger (Valtion yhtiöomistuksen historia, 2001; Kääriäinen, 1994; Miettinen, 2000; Salminen and Viinamäki, 2001). It is believed that state-ownership can no longer be an instrument of industrial policy, so reduced political control would be beneficial, as in telecommunications (Salminen and Viinamäki, 2001). Privatisation is also believed to improve the access to venture capital (which once was a motive for state-ownership).

The emphasis in the service sector and in infrastructure industries is by contrast on competition, with increased private provision as a byproduct in the case of for example competitive tendering. Like in manufacturing, the authorities also mention globalisation as a reason, but with the difference that costs are also expected to be reduced (Kohti tehokkaampaa ja laadukkaampaa julkista taloutta, 2002; Salminen and Viinamäki, 2001).

However, the official motives may not give the full explanation. Completed industrialisation does not mean that state-owned companies should be sold. Also, there was no urgent need of sales revenues when the first blueprint was commissioned. Lower wealth just reduces the state's creditworthiness and future dividend incomes. Some divestiture made entry into the EMU possible, given the budget deficit that was later caused by the depression in the 90s, but this cannot explain the extent of privatisation.

As for other motives, political influence can be reduced without privatisation (as Sonera's misguided participation in the German UMTS-auctions show). Regulated utilities may in fact be less independent after privatisation than listed state-owned companies or universities and central banks. Also, state-enterprises i Finland were not dependent on the state budget. To raise funds through the stock market does not necessarily mean lost control. To sell so as to merge may neither improve performance (Tichy, 2001; Mueller, 2001) nor social welfare. Finally, both supporters and critics of privatisation often refer to globalisation, but the EU and the WTO require only fair competition in commercial activities but no privatisation. It is up to each country to define what is a commercial activity.

It might cynically be argued that the real reason for privatisation is not a belief in social benefits but opportunism. But decision-makers are not corrupt in Finland (see Kaufmann et al., 2003), and those who decide on privatisation hardly gain personally. As for electoral success, voters might prefer politicians who oppose privatisation, as suggested by a Gallup Finland poll on local services (Helsingin Sanomat, 24.6.2003). The absence of a privatisation 
programme and high-profile election promises to privatise point in the same direction, like the use of the euphemism 'broadened ownership base'. ${ }^{5}$ But the decision-makers have a temporary monopoly because of slow changes in voting habits and the party structure.

So despite weak official motives, it seems that decision-makers act out of conviction. A recent government report emphasises the need to reduce the "size and significance of the public sector" and describes privatisation everywhere as "linked to the value and norm climate of society and to the nature of the political administrative system, power hegemonies and corresponding issues" (Salminen and Viinamäki, 2001: 56). In other words, the policy is partly about ideology and fashion, as also reflected in phrases about adapting to a new environment. ${ }^{6}$ To privatise may in addition signal how Finland has changed since cooperating with the neighbouring Soviet Union. A sensitivity to international trends is also revealed in private conversations where managers feel inferior if working in the public sector and tell about suspicions abroad because of the extent of state-ownership in Finland.

\section{Public ownership in Finland: an evaluation}

As Rees (1984: 11) points out, the performance of a public enterprise must be assessed according to the objectives that have been set for it. The mission of the state-owned companies in Finland was mainly to promote growth and industrialisation, so their success is to a large extent a question of whether this aim has been reached at reasonable costs. GDP per capita increased in Finland by a factor of 8.7 from 1913 to 1998, as compared to 4.6 in Germany, 3.8 in Britain, 6.0 in Sweden, 5.2 in the US, 5.6 in China and 14.7 in Japan (Maddison, 2001: 264). Causality is difficult to prove, but Finland's growth would hardly be second only to Japan if a strategy of a large state-enterprise sector is doomed to fail.

The emphasis on increased capital intensity may on the other hand have gone too far, as reflected in a lower growth in output per employee in Finland from the 1970s onwards (Pohjola, 1996: 124, 98-106, 30). Companies like Enso-Gutzeit and Kemira did also overinvest, but the low productivity of capital was mainly a private-sector phenomenon, as illustrated by

\footnotetext{
${ }^{5}$ The parliament blocked the privatisation of Alko's production and wholesale trade (which was separated into Altia Group), supported by popular resistance in 2001.

${ }^{6}$ Similar observations have been made in the Netherlands: "Certainly, for a small open economy such as the Netherlands it would be difficult to ignore developments elsewhere in Europe. Thus, the Dutch privatization programme can be described as a 'curtsy to the times' rather than the result of a positive, grand design to revitalise the economy" (Hulsink and Schenk, 1998: 255).
} 
Repola and Kymmene (Pohjola, 1996: 133). There has subsequently been a stronger emphasis on shareholder value from the 90s onwards, in particular among firms in foreign ownership (Ali-Yrkkö and Ylä-Anttila, 2001).

The deliberate procyclical macroeconomic policy has caused violent swings, but the crisis was less severe than elsewhere in the 30s, when many state-owned companies were established (Pekkarinen and Vartiainen, 2001). These may have affected employment by being growth-oriented, often located in disadvantaged regions, and subject to restrictions on layoffs. Public firms were however not expanding but downsized during the deep crisis of 90s, despite some rescue operations. This suggests that beneficial macroeconomic effects of wider objectives (not to be confused with persistent overmanning) cannot be ruled out.

Public ownership has been criticised for dynamic inefficiency and not just high costs, for example because of lower spending on cost-saving R\&D (Bös and Peters, 1991). But this result is driven by an assumption that the state is unable to hire a competent manager and pay her according to performance. Less is known if such restrictions are not imposed. Also, the state-owned companies in Finland have been high spenders on R\&D, and there is indirect evidence of dynamism in remaining state-owned companies or prior to privatisation.

For example, Enso was in the 90s an internationally significant producer, with several plants abroad, and is now part of Stora-Enso which is second-largest in the world (Statsbolagen 1990, 1991; Statsbolagen 1996, 1997; State Shareholdings in Finland 1991, 1992; Wikman, 1999). Outokumpu has divested its mines and is now the world's third largest steel producer after Thyssen Krupp and Arcelor, largest in stainless steel, world leader in supraconducting materials, and a provider of machinery and technology including water treatment plants (Hufvudstadsbladet, 29.11.1992 and 19.6.2003; Outokumpu Technology Awarded Two Turnkey Projects, 2002). Rautaruukki has experienced a similar transformation from steel to technology. Kemira now provides environmental cleaning and biotechnology, in addition to a wide range of chemicals, and has plants in more than 30 countries. Metso, formerly Valmet, is strong in mineral processing and automation and world leader in paper machines (State Shareholdings in Finland 1991, 1992).

Finland's most successful company Nokia, which originally made paper and rubber products, cables and light bulbs, started producing mobile phones in 1963. The state had established a producer of defence equipment, Televa, that was diversifying into electronics at that time. Televa made cables and developed digital switches and mobile phones for the domestic market and the Soviet Union. It was sold to Nokia in 1981 and merged with its electronics division. This became Telenokia, which produced a completely digital exchange (DX 
2000) in 1982 and the world's first mobile car phone in 1984 (Kasvio, 1997; Moen 2002). The state also contributed to the success of this industry through a P\&T-administration with low charges because of automatisation and subsequent digitalisation.

The Giro-system was another example of innovative and supportive state activity. It was developed because of a war-time increase in public-sector transactions with households and firms. The Giro-system created a critical mass that made the postal savings bank attractive for private customers as well. Other banks lost market shares, and had to develop similar systems (Kauko, 2000).

Finland's experiences are consistent with the positive relationship between growth and the size of the public enterprise sector (not the public sector) in Fowler and Richards (1995). Successful public ownership nevertheless flies in the face of some theories that assume public-sector decision-makers to be completely selfish. Selfishness and lack of motivation would distort the objectives of a company and lead to corruption and managerial slack. But such assumptions are not supported by experimental research, which instead emphasises fairness, reciprocity and intrinsic motivation in explaining individual behaviour, collective action and cooperation (Fehr and Schmidt, 1999; Fehr and Fishbacher, 2002; Frey, 1977).

Organisational design can cause either fairness or selfishness to dominate, and can support or crowd out intrinsic motivation (Fehr and Fishbacher, 2002; Frey, 1997).

Such factors are closely related to the quality of governance. A World Bank report by Kaufmann et al. (2003) compares observable governance indicators, such as accountability, political stability, government effectiveness, regulatory quality, rule of law, and control of corruption, in 199 countries. These indicators seem to explain growth (Jalilian et al., 2003), and their unweighted average from 2002 is highest in Finland. ${ }^{7}$ As it takes time to develop such traditions, the governance culture was probably satisfactory also 80 years ago, despite some unstability. If so, good governance is part of the explanation of Finland's growth, not least by ensuring the success of the public enterprises that had to be established.

\section{Sales revenues and restructuring}

Like in the case of public ownership, the success of privatisation is partly a question of its objectives. The government in Finland did not expect drastic cost-reductions by selling

\footnotetext{
${ }^{7}$ Switzerland ranks second highest in terms of the average governance index, whereas Italy's position is much lower. This might be reflected in opposite experiences of public ownership (Marrelli and Stroffolini, 1998; von Ungern-Sternberg, 1996).
} 
shares, so unchanged cost efficiency would not necessarily mean a failure. Success would instead require large sales revenues and industrial restructuring. As divestiture and widespread share-ownership are not ends in themselves in the same way as in Britain, firms are sold only at a satisfactory price. A setback would therefore mean postponed privatisation rather than low proceeds.

A setback occurred when the state expected Sonera's share-price to increase when it in fact peaked. Privatisation had to be postponed, whereas better timing would have yielded substantial revenues. The reason for the dramatic price fall was the misguided participation in the German UMTS-auctions, in addition to the crisis in the ITC-sector. ${ }^{8}$ Also, the parliament prevented in 2002 the government from selling Kemira, because of doubts about the potential buyer. But privatisation has in most cases proceeded as planned. The sales revenues 1991-2002 have amounted to about EUR 8,600m. This has not reduced the state's dividend incomes, which amounted to about EUR 669m in 2002 despite a decade of divestiture (Valtion Yhtiöomistus 2002, 2003; Hufvudstadsbladet, 32.5.2003).

The sales proceeds have been used for reducing public debt, but also for encouraging R\&D through universities, the Academy of Finland, and Suomen Teollisuussijoitus Oy/Industry Investment Ltd (Valtioneuvoston periaatepäätös valtion omaisuuden myynnistä vuosina 2000-2003 saatavien tulojen käytöstä, 2000). Industry Investment is a state-owned venture capital company, promoting the realisation and commercialisation of innovations by investing in private equity funds and regional or venture capital funds, with an emphasis on the ICT-sector. It also invests directly, sometimes together with other institutions, in promising companies like Finlux (with brands such as ASA and Salora), which is specialising in non-flammable television sets (Industry Investment, Annual Report 2001).

As for industrial restructuring, Stora Enso was created by merging Veitsiluoto and Enso-Gutzeit before joining Stora in Sweden, Metso by merging Rauma with parts of Valmet, and Fortum by merging IVO-group and Neste. Leonia became part of Sampo. A number of large and often international players have thus emerged, but mixed international experiences of mergers suggest a risk for future disappointments.

\footnotetext{
${ }^{8}$ Sonera was required to behave as if privatised, and the state saw itself as a passive owner when the mistaken investments were made. So were they caused by pending privatisation, remaining public ownership or by Sonera's unclear intermediate status?
} 
Privatisation can be mismanaged (Bayliss, 2001), so good governance and in particular freedom from corruption are likely success factors, like in the case of public ownership. It seems that the policy has so far achieved what was promised in Finland. But if good performance is required to get high prices and serious investors, privatisation might actually work only if state-owned firms are so well managed that there is no need to privatise.

\section{Cost efficiency and financial performance}

Cost efficiency was not the main objective for creating state-owned companies in Finland, and neither was it a reason for their privatisation. Alleged inefficiency may cause divestiture elsewhere, but a company that performs well would become more and not less likely to be privatised in Finland. This section nevertheless deals with costs and profitability in Finland, partly because of their role as a motive elsewhere, but also because of their importance for public-sector reform (Kohti tehokkaampaa ja laadukkaampaa julkista taloutta, 2002).

World Bank-sources argue that profit maximising owners subject to threats of bankruptcy and takeover have stronger incentives to reduce costs than politicians or bureaucrats. They would motivate and monitor appointed managers more efficiently than when there are wider and sometimes distorted objectives, soft budget constraints and complicated chains of command (Bureaucrats in Business, 1995). But modern theory is less dogmatic on ownership (Estrin and Pérotin, 1991).

For example, an owner-manager would indeed have strong incentives to cut costs. But to privatise a managerial firm may increase costs, because the profit motive reduces the incentive to pay for lower managerial slack (De Fraja, 1993; Willner, 2003). Public ownership may in some models, but contrary to Finland's experience, mean excessive labour intensity and private ownership the opposite, with ambiguous consequences for overall productivity (see Pint, 1991). The ranking of ownership is sensitive to details in the objective function and reward schedule if low performance means that the manager is fired (Willner and Parker, 2003). Also, privatisation often requires regulation, and hence an additional agency problem that may sometimes cost more than public ownership (Shapiro and Willig, 1990/2000; Laffont and Tirole, 1991).

Empirical comparisons of ownership are also more mixed than usually believed. Megginson and Netter (2001) and to some extent Borcherding et al. (1982) argue that the literature favours private ownership, but this interpretation is not consistent with Millward (1982), 
Boyd (1986), Dewenter and Malatesta (1997) and Willner (2001). ${ }^{9}$ Willner (2001)

summarises new contributions as well as those used by earlier authors, in general from refereed journals. The largest group of the nearly 70 sources (in general ignored by Megginson and Netter, 2001) find no difference. Public ownership may even be superior in water, electricity and insurances, whereas some labour intensive industries such as refuse collection and bus transport tend to be cheaper under private ownership (Willner, 2003).

As for companies that have become privatised, labour productivity was higher among public than private firms in the British heavy industry in 1954-79 (Iordanoglu, 2001). Also, changes after privatisation went both ways, and most improvements took place while firms were still state-owned (Martin and Parker, 1997). Similar results apply for Italy and Austria (Fraquelli and Erbetta, 2000; Schaffhauser-Linzatti and Dockner, 2001).

Unfortunately, there are few Finnish comparisons of performance, and in particular of cost efficiency or productivity. However, just before the crisis in the 90s, profitability in firms with different ownership was roughly similar in each industry (Valtionyhtiöt markkinataloudessa, 1989). This was true also for the listed state-owned companies in 1994, just before privatisation took off (Julkiset noteeratut yhtiöt, 1996). As for the recent period, state-owned and associated companies in Finland did not perform as well as Nokia but better than on average among the other listed companies, as shown in Table III.

Table III. Average Financial Performance Among Listed Companies in Finland 1997-2002

All listed companies in Finland All listed companies except for Nokia State-owned and associated companies (Source: State Shareholdings in Finland 2002:5).

$\begin{array}{cccc}\text { Profitability } & \text { Net result } & \text { Dividend yield } & \text { P/E ratio } \\ 9.5 \% & 5.8 \% & 2.1 \% & 26.7 \\ 7.6 \% & 4.3 \% & 3.3 \% & 18.0 \\ 7.8 \% & 4.4 \% & 2.7 \% & 20.4\end{array}$

A final verdict on the impact of privatisation may be premature, not least because of the macroeconomic turbulence from the late 1980s onwards. Also, mergers make it difficult to distinguish the effects of ownership and reorganisation. Legitimate non-commercial objectives may have affected performance among limited companies as well, so the interpretation of possible changes would not be unambiguous. Nevertheless, Table IV presents operating profits as a percentage of net sales before and after abandoned state majority for the most important companies under the Ministry of Trade and Industry. In addition to the years before

\footnotetext{
${ }^{9}$ Dewenter and Malatesta (1997) find higher profitability in private firms but mixed results on cost efficiency when comparing 500 public and private firms from different countries.
} 
privatisation entered the agenda (1987-1990) and the most recent period (1999-2002), the table also includes a column for 1998-2001, i.e. three years of high economic activity followed by the first signs of a recession, like $1987-1990 .^{10}$

Table IV. Operating Profits as a Percentage of Net Sales Before and After Privatisation

$\begin{array}{lccc} & 1987-90 & 1998-2001 & 1999-2002 \\ \text { Enso-Gutzeit/Stora Enso } & 11.31 \% & 12.26 \% & 11.33 \% \\ \text { Outokumpu } & 9.41 \% & 5.72 \% & 6.45 \% \\ \text { Rautaruukki } & 12.29 \% & 4.46 \% & 2.89 \% \\ \text { Sisu/Partek } & 5.94 \% & 5.08 \% & \text { n.a. } \\ \text { Valmet/Metso } & 1.10 \% & 4.29 \% & 4.96 \% \\ \text { Veitsiluoto/Stora Enso } & 11.52 \% & 12.26 \% & 11.33 \%\end{array}$

(Sources: 1987-90: Balance-sheet information from Statsbolagen 1987, Statsbolagen 1989; Statsbolagen 1990; 1998-2001: As presented in State Shareholdings in Finland 2001; 1999-2002: Valtion Yhtiöomistus 2002).

Although little is known about cost efficiency, dramatic improvements would be surprising given these unsystematic changes in financial performance. The lack of systematic improvements might be explained by governance-related factors as in section 5, but also by the fact that state-ownership was not caused by rescuing badly performing private firms as often elsewhere. Mobility among managers between public and private firms may be another reason (Estrin and Pérotin, 1991). Both types of firms have in addition belonged to the same employers' association, like in Denmark but not Sweden. Central bargaining has equalised wages among otherwise similar firms, which might explain why wage costs have not been higher in state-owned firms, as for example in Italy (Marrelli and Stroffolini, 1998).

Wage costs may on the other hand be crucial in public-sector reforms that are expected to save money. Health-care is a case in point, but earlier experiences of public and private provision are mixed, and costs per capita tend to be higher in countries dominated by private provision (Böckerman, 1997; Puoskari and Taimio, 2002). ${ }^{11}$ The public sector in Finland is efficient in an international comparison. Productivity increased by $0.5-5.2 \%$ in public hospitals, health-centres, old-people's homes and theatres. But causality is hard to assess, because the increase was often even higher in core public-sector activities that were not subject to

${ }^{10}$ A more detailed comparison of Enso-Gutzeit/Enso and its leading private competitors Metsä-Serla and Kymmene (later UPM-Kymmene) during the last decade before privatisation suggests no evidence for lower performance in Enso, nor any dramatic change after privatisation (Wikman, 1999).

${ }^{11}$ For example, there were no differences in dentistry in value of output per hour, but controlling for output-mix and market characteristics suggest somewhat lower public-sector productivity (Sintonen, 1988). 
competition, such as land survey offices (10.4\%), tax offices $(0.9 \%)$ and employment offices (26.0\%) (Kohti tehokkaampaa ja laadukkaampaa julkista taloutta, 2002; Hjerppe and Luoma, 1997).

Private provision has often increased in local authorities because of competition, which may be more important than privatisation as such. Competitive tendering caused net costs to fall by about $18 \%$ and $7-10 \%$ in meals-on-wheels and street maintenance in Helsinki, although quality changes raise concerns about comparability (Kähkönen, 2001; see also section 8$).{ }^{12}$ Net costs were reduced by about $14 \%$ in local bus transport, but this figure may be inaccurate because of pending court decisions after severe conflicts with the employees (Kähkönen, 2001). Also, some of the most efficient bus companies had to quit, as they were small and not able to organise bids (Anttila, 1997). As for school cleaning, net costs in fact increased by $14 \%$, so the city chose to return to in-house provision (Kähkönen, 2001).

\section{Consumer benefits, quality and social welfare}

Cost efficiency is just one component of the total surplus by which we usually define allocative efficiency or social welfare. Social welfare can be reduced despite lower costs and vice versa. But it can also increase despite a fall in consumer welfare, so it may make sense to analyse distributional effects and quality as well.

The possible benefits of privatisation can be overshadowed by higher profit margins, in particular if there is also higher concentration because of mergers. Many state-owned companies have in addition represented low-elasticity industries, so the combination of profit maximisation and more concentration may increase the deadweight loss of imperfect competition (Willner and Ståhl, 1992). Economic integration can in principle compensate for the increased domestic concentration, but mergers may also aim at offsetting the competition that integration was meant to achieve (Neumann et al., 1985; Sugden, 1983). There can also be adverse effects on wages, working conditions and quality, so an assessment of the welfare change requires that all stakeholders are accounted for.

To highlight the need to account for both winners and losers, suppose that a not-forprofit public monopoly is replaced by an $n$-firm Cournot-oligopoly, thus changing the price from $p_{0}$ to $p_{1}$. The post-privatisation price elasticity of demand is $\eta$. Marginal costs are $c$ under private ownership and $k c$ in the public monopoly, whereas fixed costs, and hence the

\footnotetext{
${ }^{12}$ Net costs mean that the costs caused by the tendering process are also accounted for. The percentages in this paragraph are calculated from figures in Kähkönen (2001).
} 
costs of duplication, are negligible. A lower price means a higher consumer surplus, but also a higher total surplus if $k>1$ only because of better wages and working conditions, because the workers' internal rent capture is part of the total surplus, like the profits. The price-cost margin is $(k-1) c$ before and $p_{1}-c$ after privatisation, which then reduces the price only if $k>\eta n /(\eta n-1) .{ }^{13}$ Only a very large $k$ can therefore make $p_{1}$ lower than $p_{0}$ if demand elasticity is low and the competitors are few, as often in former public monopolies. For example, $n=4$ and $\eta=0.5$ would require a $50 \%$ marginal cost reduction.

Privatisation in manufacturing and banking may not as such have affected social welfare in Finland because of the preceding profit orientation and the absence of any visible ownership effects on efficiency, unless the mergers turn out to be misguided. But pay and working conditions were for example better in municipal bus companies (Mäkeläinen and Pirttinen, 2000), often because of different collective agreements. Competitive tendering has often also led to redundancies, harder work and lower pay, not only in Finland (Kohtamäki, 2000; Anttila, 1997; Kähkönen, 2001; White, 1990). There have been similar concerns about the impact on staff welfare in property maintenance (Helsingin Sanomat, 30.11.1997).

Competition can sometimes also reduce quality and coordination in industries that are not natural monopolies, or lead to cream-skimming. For example, the cost reductions in meals-on-wheels and street-maintenance in Helsinki may have reduced quality (Kähkönen, 2001). Also, Engel Group lost all tenders in property maintenance while still in state-ownership, until it learned to leave as much dust in the corridors as the competitors did (Helsingin Sanomat, 30.11.1997).

Frequency is the most important quality dimension in urban public transport, and a reduction would favour the use of cars (Bussiammattilainen, 1994, no. 5: 10-11 and 8-9; Goodwin, 1993). Bus deregulation in Britain often led to reduced frequency and deteriorated coordination, with ambiguous effects on the total surplus because of the large increase in profits (Tyson, 1990; White, 1990; Oldale, 1997). Costs were reduced in Sweden as well, but waiting times and prices increased (Alexandersson et al., 1996). However, services in Finland were cut by the local authorities before competitive tendering. Frequency, route network and rolling stock remained under local authority control afterwards, so deregulation as such caused no quality reduction (Haatainen, 2000; Kähkönen, 2001). ${ }^{14}$

\footnotetext{
${ }^{13}$ Note that $p_{0}=k c$ and that $p_{1}$ can be written $\eta n c /(\eta n-1)$.

${ }^{14}$ However, there were other repercussions, as the bus manufacturer Carrus was sold to Volvo in 1997 (and later partly relocated to Poland), because of concerns about customer stability (Kurkinen, 2001: 377).
} 
Some evidence suggests welfare maximising prices when telecommunications belonged to the PT-administration, at least in the case of fixed domestic long-distance calls (Björkroth and Willner, 2002). This and technical dynamism led to low charges. There were no high profit margins to be reduced by competition, so technical progress may have been more important than deregulation, which is also associated with social costs because of duplication and 'confusion marketing' (Björkroth and Willner, 2002 and 2003). Tariffs may even increase by deregulation if a former welfare-maximiser is required to set prices high enough to ensure competition. ${ }^{15}$ But competition would then be treated as an end in itself that it is worth paying for, rather than as one of several alternative tools to achieve low prices.

The incumbent has in most cases in Finland remained in public ownership, but the objectives have changed. For example, railway tickets have become more expensive, and less profitable services are threatened by cuts. Some profitable suburban services may become subject to tendering and takeover in the future, although the incumbent VR-yhtiöt has high labour productivity and is more efficient than its US-counterparts (Lehto, 1997b). The number of post offices has been reduced by $40 \%$ and profit margins have increased (Lehto, 1997c). Larger parcels and business mailings may become subject to competition.

We may conclude that social welfare has hardly changed because of privatisation in manufacturing and banking, because of the absence of a change in objectives and the lack of evidence of an ownership effect on financial performance and cost efficiency. But the mergers may be a reason for concern in the future, and a return to non-commercial objectives might require renationalisation. Costs have been reduced in the service sector, maybe because of competition rather than privatisation. But these reductions may not be large enough to compensate for the adverse effects on consumers and employees.

\section{Concluding remarks: Lessons to be learned}

Finland's state-owned manufacturing sector is larger than in most countries, despite some privatisation that has partly been motivated by ideology and fashion and partly by a desire to fund R\&D and secure entry into the EMU. The policy has achieved its aims, not least because of the presence of fairly well-run companies to sell. Privatisation as such has hardly changed welfare, but a return to wider objectives might be difficult. Privatisation and/or

\footnotetext{
${ }^{15}$ For example, the German incumbent, Deutsche Telecom, has been criticised for predatory pricing. Its competitors favour regulation that keeps prices high enough to sustain competition (Haucap and Kruse, 2002).
} 
competition has reduced costs in the service-sector, but cost-cutting may then affect consumers and staff adversely. The net effect on social welfare is therefore ambiguous. It follows that Finland's experiences can hardly be used as an argument for a drastic reduction of public ownership.

The experiences of public ownership are on the hand less positive in the third world than in industrialised countries. But a World Bank report admits that domestic privatisation may be of little help in less developed countries (Bureaucrats in Business, 1995). This is consistent with the view of underdevelopment as a matter of bad governance, so that neither public nor private activities are successful (Kaufmann et al., 2003; Jalilian et al., 2003). To become a subsidiary economy owned by transnationals may on the other hand neither be politically feasible nor desirable, and the kind of foreign entrepreneurs that became naturalised Finns in the 19:th century may not be available. Only well-run state-enterprises from developed countries might therefore be able to transmit the necessary culture of good governance, by becoming partners in joint-ventures for a limited period.

\section{REFERENCES}

\section{Books, articles and research reports}

Alexandersson, Gunnar, Staffan Hultén and Stefan Fölster (1996), How Efficient is the Competitive Tendering in Sweden? An Evaluation of the Deregulation of the Market for Public Bus Services, Mimeo, Stockholm School of Economics.

Ali-Yrkkö, Jyrki and Pekka Ylä-Anttila (2001), 'Globalisation of Business in a Small Country - Does Ownership Matter?', The Research Institute of the Finnish Economy, Discussion papers, No. 779.

Anttila, Tero (1997), 'Linja-autoliikenteen kilpailuttaminen', pp. 291-313 in Lehto, Eero (Ed.), Monopoli vai kilpailu? Yksityistäminen, sääntely ja kilpailurajat, Helsinki/Juva: Atena.

Aura, Teuvo (1962a), 'Valtion liiketoiminta', pp. 16-22 in Aura, Teuvo, Talous ja yhteiskunta. Puheita ja puheenvuoroja, Kuopio, 1962.

Aura, Teuvo (1962b), 'Hyvinvoinnin rakennuspuita', pp. 56-60 in Aura, Teuvo, Talous ja yhteiskunta. Puheita ja puheenvuoroja, Kuopio, 1962.

Bayliss, Kate (2001), 'The World Bank and Privatisation: A Flawed Development Tool', Global Focus, vol. 13, June.

Björkroth, Tom and Johan Willner (2002), 'Deregulation and Corporate Behaviour. An Analysis if Long-distance Telecommunication Charges', paper presented at the 29:th Earie conference, Madrid, September 5th-8th, 2002.

Björkroth, Tom and Johan Willner (2003), 'Liberalisation and Technical Change in Finland', in Hulsink, Willem and Emiel F. M. Wubben (Eds.), On Creating Competition and Strategic Restructuring. Regulatory Reform in Public Utilities, Cheltenham: Edward Elgar (forthcoming 2003).

Böckerman, Petri (1997), 'Kuntapalvelujen kilpailuttaminen', pp. 367-389 in Lehto, Eero (Ed.), Monopoli vai kilpailu? Yksityistäminen, sääntely ja kilpailurajat, Helsinki/Juva: Atena. 
Borcherding, Thomas E., Werner W. Pommerehne and Friedrich Schneider (1982), 'Comparing the Efficiency of Private and Public Production: The Evidence from Five Countries', Zeitschrift für Nationalökonomie, Suppl. 2, 127-156.

Bös, Dieter and Wolfgang Peters (1991), 'Privatization of Public Enterprises. A Principal-Agent Approach Comparing Efficiency in Private and Public Sectors, Empirica, vol. 18, no. 1, pp. 5-16.

Boyd, Colin W. (1986), 'The Comparative Efficiency of State Owned Enterprises', in Negandhi, Anant R. (ed.), Multinational Corporations and State-Owned Enterprises: A New Challenge in International Business, Greenwich, Conn. and London: Research in International Business and International Relations, JAI Press.

Bureaucrats in Business. The Economics and Politics of Government Ownership (1995), Published for the World Bank, Oxford: Oxford University Press.

Bussiammattilainen (1994), no. 5, pp. 8-9 and 10-11.

Cowling, Keith and Roger Sugden (1998), 'The Essence of the Modern Corporation: Markets, Strategic Decision-Making and the Theory of the Firm', The Manchester School, vol. 66, no. 1, pp. 59-86.

Cremér, H., Marchand, M. and J. F. Thisse (1989), 'The Public Firm as an Instrument for Regulating an Oligopolistic Market', Oxford Economic Papers, vol. 41, April, 283-301.

De Fraja, Giovanni (1993), 'Productive Efficiency in Public and Private Firms', Journal of Public Economics, vol. 50, no. 1 , pp. 15-30.

De Fraja, Giovanni and Flavio Delbono (1989), 'Alternative Strategies of a Public Enterprise in Oligopoly', Oxford Economic Papers, vol. 41, April, pp. 302-311.

Dewenter, Kathryn and Paul H. Malatesta (1997), 'Public Offerings of State-Owned and Privately-Owned Enterprises: An International Comparison', Journal of Finance, vol. 52, pp. 1659-79.

Estrin, Saul and Virginie Pérotin (1991), 'Does Ownership Always Matter?', International Journal of Industrial Organization, vol. 9, no. 1, pp. 1-170.

Fehr, Ernst and Klaus M. Schmidt (1999), 'A Theory of Fairness, Competition and Cooperation', Quarterly Journal of Econmics, vol. 114, no. 3, pp. 817-868.

Fehr, Ernst and Urs Fischbacher (2002), 'Why Social Preferences Matter - The Impact of Non-Selfish Motives on Competition, Cooperation and Incentives', Economic Journal, vol. 112, no. 478, pp. C1-C33.

Fraquelli, Giovanni and Fabrizio Erbetta (2000), 'Privatisation in Italy: an Analysis of Factor Productivity and Technical Efficiency', pp. 537 and 557 in Parker, David (Ed.), Privatisation and Corporate Performance. Aldershot: Edward Elgar.

Geroski, Paul (1995), 'What Do We Know About Entry?', International Journal of Industrial Organization, vol. 13, no. 4, pp. 421-440.

Goodwin, P. B. (1993), 'Car Ownership and Public Transport Use: Revisiting the Interaction', Transportation, vol. 27 , no. 1 , pp. 21-33.

Granqvist, Nina (1997), Privatisering i princip och praktik. En studie av privata inslag i de finländska kommunernas verksamhet, Åbo: Åbo Akademis förlag.

Haatainen, Jaana (2000), 'Bussiliikenteen kilpailuttamisen vaikutukset palveluihin ja niiden laatuun', pp. 65-95 in Aarrevaara, Timo, Jaana Haatainen, Risto Harisalo and Jari Stenwall (Eds.), Kilpailuttaminen joukkoliikenteessä - Kilpailuttamisen vaikutusten kartoittaminen, Tampere: Tampereen Yliopisto, Hallintotieteen laitos.

Haucap, Justus and Jörn Kruse (2002), 'Predatory Pricing on the Liberalised Telecommunications Markets', paper presented at the International Telecommunications Society, $13^{\text {th }}$ European Regional Conference, Madrid, 8-10.9.2002. 
Hausman, William J. and John L. Neufeld (1999), 'Falling water: The origins of direct federal participation in the U.S. electric utility industry 1902-1933', Annals of Public and Cooperative Economics, vol. 76, no. 1, pp. 49-74.

Hjerppe, Reino and Kalevi Luoma (1997), 'Finnish Experiences in Measuring and Promoting Productivity in the Public Sector', Government Institute for Economic Research, Discussion papers, 150, Helsinki.

Holmström, Bengt and Paul Milgrom (1991), 'Multi-Task Principal-Agent Analyses: Incentive Contracts, Asset Ownership and Job Design', Journal of Law, Economics and Organization, vol. 7, pp. 972-91.

Hulsink, Willem and Hans Schenk (1998), 'Privatisation and Deregulation in the Netherlands', pp. 242-257 in Parker, David (ed.): Privatisation in the European Union: Theory and Policy Perspectives, London and New York: Routledge.

Iordanoglu, Christafis H. (2001), Public Enterprise Revisited. A Clooser Look at the 1954-79 UK Labour Productivity Record, Cheltenham, UK and Northampton, US: Edward Elgar.

Jalilian, Hossein, Colin Kirkpatrick and David Parker (2003), 'The Impact of Regulation on Economic Growth in Developing Countries: A Cross-Country Analysis', mimeo.

Kääriäinen, Seppo (1994), 'Omistuspohjan laajentamisesta voimaa teollisuuden kehittämiseen', Uudistuva teollisuus, valtionyhtiöt ja yksityistäminen, Helsinki: Kauppa- ja Teollisuusministeriö.

Kähkönen, Liisa (2001), 'Kilpailuttamisen kustannusvaikutukset Helsingin kaupungin bussiliikenteessä, kotipalvelun ateriapalveluksessa, katujen kunnossapidossa ja koulusiivouksessa, Helsingin kaupungin tietokeskus, Tutkimuksia 2001:5

Kasvio, Antti (1997), 'Finland's road to the Information Society', paper prepared for the Finnish Sociological Congress.

Kaufmann, Daniel, Aart Kraay and Massimo Mastruzzi (2003), 'Governance Matters III: Governance Indicators for 1996-2002', mimeo, The World Bank.

Kauko, Karlo (2000), The Microeconomics of Innovation: Oligopoly Theoretic Analyses with Application to Banking and Patenting, Helsinki/Jyväskylä: Bank of Finland Studies E:18.

Kekkonen, Urho (1952), Onko maallamme malttia vaurastua?, 2:nd ed., Helsinki: Otava.

Kohtamäki, Vuokko (2000), 'Bussiliikenteen kilpailuttamisen talodellisista vaikutuksista', pp. 26-44 in Aarrevaara, Timo, Jaana Haatainen, Risto Harisalo and Jari Stenwall (Eds.), Kilpailuttaminen joukkoliikenteessä - Kilpailuttamisen vaikutusten kartoittaminen, Tampere: Tampereen Yliopisto, Hallintotieteen laitos.

Knoellinger, Carl-Erik (1935), Jämförande studier rörande kreditväsendets organisation med särskild hänsyn till konkurrensen mellan affärsbanker och sparbanker, Åbo: Åbo Tidnings- och Tryckeri AB.

Kurkinen, Jari (2001), Suomen autokoriteollisuuden historia, Jyväskylä: Autokoriteollisuus ry.

Laffont, J.-J. and J Tirole (1991), 'Privatization and Incentives', Journal of Law, Economics and Organization, vol. 7, Spring, pp. 84-105.

Lehto, Eero (1997a), 'Sähkömarkkinat ja kilpailu', pp. 162-199 in Lehto, Eero (Ed.), Monopoli vai kilpailu? Yksityistäminen, sääntely ja kilpailurajat, Helsinki/Juva: Atena.

Lehto, Eero (1997b), 'Kilpailuako rautateille?', pp. 274-290 in Lehto, Eero (Ed.), Monopoli vai kilpailu? Yksityistäminen, sääntely ja kilpailurajat, Helsinki/Juva: Atena.

Lehto, Eero (1997c, 'Postipalvelut ja markkinamekanismi', pp. 218-235 in Lehto, Eero (Ed.), Monopoli vai kilpailu? Yksityistäminen, sääntely ja kilpailurajat, Helsinki/Juva: Atena.

Maddison, Angus (2001), The World Economy. A Millennial Perspective. Paris: OECD. 
Mäkeläinen, Ulla and Susanna Pirttinen (2000), 'Bussiliikenteen kilpailuttamisen henkilöstövaikutukset', pp. 45-64 in Aarrevaara, Timo, Jaana Haatainen, Risto Harisalo and Jari Stenwall (Eds.), Kilpailuttaminen joukkoliikenteessä - Kilpailuttamisen vaikutusten kartoittaminen, Tampere: Tampereen Yliopisto, Hallintotieteen laitos.

Marrelli, Massimo and Francesca Stroffolini (1998), 'Privatisation in Italy: a Tale of 'Capture', pp. 150-171 in Parker, David (ed.): Privatisation in the European Union: Theory and Policy Perspectives, London and New York: Routledge.

Martin, Stephen and David Parker (1997), The Impact of Privatisation. Ownership and Corporate Performance in the UK, London and New York: Routledge.

Megginson, W.L. and J. M. Netter (2001), 'From State to Market: A Survey of Empirical Studies on Privatization', Journal of Economic Literature, vol XXXIX, no. 2, pp. 321-389.

Miettinen, Topi (2000), 'Poikkeavatko valtionyhtiöt yksityisistä?', The Research Institute of the Finnish Economy, Discussion Papers No. 730.

Millward, R. (1982), 'The Comparative Performance of Public and Private Ownership', in Roll, Lord E. (ed.), The Mixed Economy, London: Macmillan.

Moen, Eli (2002), Globalisering og industripolitiske straegier. En sammenligning av Finland og Norge, Oslo: Makt- og demokratiutredningens rapportserie, Rapport 41.

Mueller, Dennis C. (2001), 'Rethinking EU Merger Policy', paper presented at the V:th Annual EUNIP conference.

Neumann, M., I. Böbel, and A. Haid (1985), 'Domestic Concentration, Foreign Trade and Economic Performance', International Journal of Industrial Organization, vol. 3, March, pp. 1-19.

Oldale, Alison (1997), 'Local Bus Deregulation and Timetable Instability', Working Paper, The Economics of Industry Group, London School of Economics.

Parker, David, Ed. (1998), Privatisation in the European Union. Theory and Policy Perspectives, London and New York: Routledge.

Parris, Henry, Pierre Pestieau and Peter Saynor (1987), Public Enterprise in Western Europe, London: Croom Helm.

Pekkarinen, Jukka and Juhana Vartiainen (2001), Finlands ekonomiska politik. Den långa linjen 1918-2000, Uppsala: Stiftelsen Fackföreningens institut för ekonomisk forskning.

Pint, Ellen M. (1991), 'Nationalization vs. Regulation of Monopolies: The Effects of Ownership on Efficiency', Journal of Public Economics, vol. 44, no. 2, pp. 131-164.

Pohjola, Matti (1996), Tehoton pääoma. Uusi näkökulma taloutemme ongelmiin, Porvoo: WSOY.

Puoskari, Pentti and Heikki Taimio (2002), Suomen julkisen sektorin tila ja tulevaisuuden näkymät, Helsinki: Palkansaajien Tutkimuslaitos, Tutkimuksia 86.

Rees, Ray (1984), Public Enterprise Economics, Second Ed., London: Weidenfeld and Nicholson.

Salminen, Ari and Olli-Pekka Viinamäki (2001), Market Orientation in the Finnish Public Sector. From Public Agency to Privatised Company, Minisatry of Finance and University of Vaasa, Research Reports 2/2001, Helsinki.

Schaffhauser-Linzatti, Michaela M. and E. J. Dockner (2001), 'The Financial and Operating Performance of Privatized Firms in Austria', mimeo, University of Vienna. 
Shapiro, Carl and Robert D. Willig (1990), 'Economic Rationales for the Scope of Privatization', pp. 55-87 in Suleiman, Ezra N. and John Waterbury (eds.), The Political Economy of Public Sector reform and Privatization, Boulder CO: Westview Press; also pp. 39-71 in Parker, David (ed.), Privatisation and Corporate Performance, International Library of Critical Writings in Economics 123, Cheltenham: Edward Elgar, 2000.

Sintonen, Harri (1988), 'Comparing the productivity of public and private dentistry', pp. 219-234 in Culyer, A. J. and Bengt Jönsson (eds.), Public and Private Health Services. Complementarities and Conflicts, Oxford: Blackwell.

Spence, A. Michael (1975), 'Monopoly, Quality, and Regulation', Bell Journal of Economics, vol. 6, no. 2, pp. 417-429.

Sugden, Roger (1983), 'The Degree of Monopoly, International trade, and Transnational Corporations', International Journal of Industrial Organization, vol. 1, June, pp. 165-188.

Tichy, Gunther (2001), 'What do we Know of the Success and Failure of Mergers', Journal of Industry, Competition and Trade, vol. 1, no. 4, pp. 347-374.

Tyson, W. J., (1990), 'Effects of Deregulation on Service Co-ordination in the Metropolitan Areas', Journal of Transport Economics and Policy, vol. 24, no. 3, pp. 283-295.

Valtionyhtiöt markkinataloudessa (1989), Liiketaloustieteen tutkimuslaitos, Helsinki.

von Ungern-Sternberg, Thomas (1996), 'The limits of competition: Housing insurance in Switzerland', European Economic Review, vol. 40, pp. 1111-1121.

White, Peter J. (1990), 'Bus Deregulation: A Welfare Balance Sheet', Journal of Transport Economics and Policy, vol. 24, no. 3, pp. 311-332.

Wikman, Daniel (1999), Privatisering av offentligt ägda företag - en studie om privatiseringen av Enso Oy, unpublished Master's Thesis, Department of Economics and Statistics, Åbo Akademi University.

Willner, Johan (1998). 'Privatisation in the Nordic EU-countries - Fashion or Necessity?, pp. 172-190 in Parker, David (ed.), Privatisation in the European Union: An Industrial Policy Perspective, London and New York: Routledge.

Willner, Johan (1999), 'Policy Objectives and Performance in a Mixed Market With Bargaining', International Journal of Industrial Organization, vol. 17, no. 1, pp. 137-145.

Willner, Johan (2001), 'Ownership, Efficiency, and Political Interference', European Journal of Political Economy, vol. 17, no. 4, pp. 723-748.

Willner, Johan (2003), 'Privatization - A Sceptical Analysis', Ch. 4 in Parker, David and David Saal (Eds.), International Handbook of Privatisation, Cheltenham: Edward Elgar (forthcoming July 2003).

Willner, Johan and David Parker (2003), 'The Relative Performance of Public and Private Enterprise under Conditions of Active and Passive Ownership', mimeo, Åbo akademi University and Aston Business School/The Centre on Regulation and Competition, IDPM, University of Manchester.

Willner, Johan and Leila Ståhl (1992), 'Where are the Welfare Losses of Imperfect Competition Large?, European Journal of Political Economy, vol. 8, pp. 477-491.

\section{Newspaper Articles}

Helsingin Sanomat, 30.11.2003, ('Palkka putosi ja työt lisääntyivät', Talous ja työ,p. E2).

Helsingin Sanomat, 24.6.2003 ('KTV:n kysely: Peruspalvelut halutaan pitää kunnallisina', accessed 24.6.2003 through http://www.helsinginsanomat.fi).

Hufvudstadsbladet, 29.11.2002, p. 11 ('Outokumpu minskar skulder'). 
Hufvudstadsbladet, 9.12.2002, p. 6 ('Männen styr styrelserna').

Hufvudstadsbladet, 23.5.2003, p. 11 ('Statligt ägande under lupp').

Hufvudstadsbladet, 19.6.2003, p. 12 ('Lågkonjunkturen hot mot nya satsningar')

\section{Government Documents}

Ajankohtainen näkemys (2003), Ministry of Trade and Industry, http://www.reputation.fi/ktm/ajankohtaista/, issued 17.4.2003; accessed 23.5.2003.

Government Decision on the State's Corporate Ownership Policies (2001), Ministry of Trade and Industry, 16.9.2001: Helsinki (also reprinted as Appendix 1 in Kaisanlahti, 2001).

Kohti tehokkaampaa ja laadukkaampaa julkista taloutta (2002), Valtiovarainministeriön työryhmä, VM128:00/2001, Keskustelualoitteita nro 70, Valtionvarainministeriö [Ministry of Finance]: Helsinki.

Omistuspohjan laajentaminen (2002), Ministry of Trade and Industry, http://www.reputation.fi.ktm/tilastot/, updated 1.11.2002; accessed 21.11.2002.

Press release, 18.9.1996, Ministry of Trade and Industry: Helsinki.

Press release, 2.8.1996, Ministry of Trade and Industry: Helsinki.

State Shareholdings in Finland 2001 (2002), Helsinki/Helsingfors: Handels- och Industriministeriet [Ministry of Trade and Industry].

Statsbolagen 1987 (1988), Helsinki/Helsingfors: Handels- och Industriministeriet [Ministry of Trade and Industry].

Statsbolagen 1989 (1990), Helsinki/Helsingfors: Handels- och Industriministeriet [Ministry of Trade and Industry].

Statsbolagen 1990 (1991), Helsinki/Helsingfors: Handels- och Industriministeriet [Ministry of Trade and Industry].

Statsbolagen 1995 (1996), Helsinki/Helsingfors: Handels- och Industriministeriet [Ministry of Trade and Industry].

Valtioneuvoston periaatepäätös valtion omaisuuden myynnistä vuosina 2000-2003 saatavien tulojen käytöstä (2000), Kauppa- ja Teollisuusministeriö [Ministry of Trade and Industry], 26.5: Helsinki.

Valtion yhtiöomistuksen historia (2001), Ministry of Trade and Industry, http://www.reputation.fi/valtion_omistajapolitiikka/, updated 10.10.2001; accessed 21.11.2002.

Valtion yhtiöomistus 2002 (2003), Helsinki: Kauppa- ja Teollisuusministeriö [Ministry of Trade and Industry]. Valtionyhtiöiden hallituksiin löytyy päteviä naisia (2003), Ministry of Trade and Industry, Press Release, 14.03.2003, http://www.reputation.fi/ktm/ajankohtaista/, accessed 23.5.2003.

Valtionyhtiöt ja osakkuusyhtiöt (2002), Ministry of Trade and Industry, http://www.reputation.fi/ktm/tilastot/, updated 13.11.2002; accessed 21.11.2002.

Valtionyhtiöt ja osakkuusyhtiöt (2003), Ministry of Trade and Industry, http://www.reputation.fi/ktm/tilastot/, updated 23.4.2003; accessed 23.5.2003.

Visio yksityistämisestä Suomessa (1991), Kauppa- ja Teollisuusministeriö [Ministry of Trade and Industry], 12.2: Helsinki.

\section{Documents from Companies and their Organisations}

Industry Investment (2002), Annual Report 2001, Helsinki.

Julkiset noteeratut yhtiöt 1996, Lahti: Opstock, Oko-Osuuspankit, 1996. 
MB Funds Lead the Acquisition of Medivire (2002), MB Funds, Press release, 11.2.2002, http;//www.mbfunds.com/tiedotteet/, accessed 29.11.2002.

Outokumpu Technology Awarded Two Turnkey Projects (2002), Outokumpu Technology, Press Release, 11.10.2002, http://www.outokumpu.com/corporat/info/, accessed 13.12.2002. 


\section{CESifo Working Paper Series}

(for full list see www.cesifo.de)

947 Erkki Koskela and Mikko Puhakka, Stabilizing Competitive Cycles with Distortionary Taxation, May 2003

948 Steffen Huck and Kai A. Konrad, Strategic Trade Policy and Merger Profitability, May 2003

949 Frederick van der Ploeg, Beyond the Dogma of the Fixed Book Price Agreement, May 2003

950 Thomas Eichner and Rüdiger Pethig, A Microfoundation of Predator-Prey Dynamics, May 2003

951 Burkhard Heer and Bernd Süssmuth, Cold Progression and its Effects on Income Distribution, May 2003

952 Yu-Fu Chen and Michael Funke, Labour Demand in Germany: An Assessment of NonWage Labour Costs, May 2003

953 Hans Gersbach and Hans Haller, Competitive Markets, Collective Decisions and Group Formation, May 2003

954 Armin Falk, Urs Fischbacher, and Simon Gächter, Living in Two Neighborhoods Social Interactions in the LAB, May 2003

955 Margarita Katsimi, Training, Job Security and Incentive Wages, May 2003

956 Clemens Fuest, Bernd Huber, and Jack Mintz, Capital Mobility and Tax Competition: A Survey, May 2003

957 Edward Castronova, The Price of 'Man' and 'Woman': A Hedonic Pricing Model of Avatar Attributes in a Synthetic World, June 2003

958 Laura Bottazzi and Marco Da Rin, Financing Entrepreneurial Firms in Europe: Facts, Issues, and Research Agenda, June 2003

959 Bruno S. Frey and Matthias Benz, Being Independent is a Great Thing: Subjective Evaluations of Self-Employment and Hierarchy, June 2003

960 Aaron Tornell and Frank Westermann, Credit Market Imperfections in Middle Income Countries, June 2003

961 Hans-Werner Sinn and Wolfgang Ochel, Social Union, Convergence and Migration, June 2003 
962 Michael P. Devereux, Measuring Taxes on Income from Capital, June 2003

963 Jakob de Haan, Jan-Egbert Sturm and Bjørn Volkerink, How to Measure the Tax Burden on Labour at the Macro-Level?, June 2003

964 Harry Grubert, The Tax Burden on Cross-Border Investment: Company Strategies and Country Responses, June 2003

965 Kirk A. Collins and James B. Davies, Measuring Effective Tax Rates on Human Capital: Methodology and an Application to Canada, June 2003

966 W. Steven Clark, Using Micro-Data to Assess Average Tax Rates, June 2003

967 Christopher Heady, The 'Taxing Wages' Approach to Measuring the Tax Burden on Labour, June 2003

968 Michael P. Devereux and Alexander Klemm, Measuring Taxes on Income from Capital: Evidence from the UK, June 2003

969 Bernhard Eckwert and Itzhak Zilcha, The Effect of Better Information on Income Inequality, June 2003

970 Hartmut Egger and Josef Falkinger, The Role of Public Infrastructure for Firm Location and International Outsourcing, June 2003

971 Dag Morten Dalen and Trond E. Olsen, Regulatory Competition and Multi-national Banking, June 2003

972 Matthias Wrede, Tax Deductibility of Commuting Expenses and Residential Land Use with more than one Center, June 2003

973 Alessandro Cigno and Annalisa Luporini, Scholarships or Student Loans? Subsidizing Higher Education in the Presence of Moral Hazard, June 2003

974 Chang Woon Nam, Andrea Gebauer and Rüdiger Parsche, Is the Completion of EU Single Market Hindered by VAT Evasion?, June 2003

975 Michael Braulke and Giacomo Corneo, Capital Taxation May Survive in Open Economies, July 2003

976 Assar Lindbeck, An Essay on Welfare State Dynamics, July 2003

977 Henrik Jordahl and Luca Micheletto, Optimal Utilitarian Taxation and Horizontal Equity, July 2003

978 Martin D. D. Evans and Richard K. Lyons, Are Different-Currency Assets Imperfect Substitutes?, July 2003

979 Thorsten Bayindir-Upmann and Frank Stähler, Market Entry Regulation and International Competition, July 2003 
980 Vivek Ghosal, Firm and Establishment Volatility: The Role of Sunk Costs, Profit Uncertainty and Technological Change, July 2003

981 Christopher A. Pissarides, Unemployment in Britain: A European Success Story, July 2003

982 Wolfgang Buchholz, Richard Cornes, and Wolfgang Peters, On the Frequency of Interior Cournot-Nash Equilibria in a Public Good Economy, July 2003

983 Syed M. Ahsan and Panagiotis Tsigaris, Choice of Tax Base Revisited: Cash Flow vs. Prepayment Approaches to Consumption Taxation, July 2003

984 Campbell Leith and Jim Malley, A Sectoral Analysis of Price-Setting Behavior in US Manufacturing Industries, July 2003

985 Hyun Park and Apostolis Philippopoulos, Choosing Club Membership under Tax Competition and Free Riding, July 2003

986 Federico Etro, Globalization and Political Geography, July 2003

987 Dan Ariely, Axel Ockenfels and Alvin E. Roth, An Experimental Analysis of Ending Rules in Internet Auctions, July 2003

988 Paola Conconi and Carlo Perroni, Self-Enforcing International Agreements and Domestic Policy Credibility, July 2003

989 Charles B. Blankart and Christian Kirchner, The Deadlock of the EU Budget: An Economic Analysis of Ways In and Ways Out, July 2003

990 M. Hasham Pesaran and Allan Timmermann, Small Sample Properties of Forecasts from Autoregressive Models under Structural Breaks, July 2003

991 Hyun Park, Apostolis Philippopoulos and Vangelis Vassilatos, On the Optimal Size of Public Sector under Rent-Seeking competition from State Coffers, July 2003

992 Axel Ockenfels and Alvin E. Roth, Late and Multiple Bidding in Second Price Internet Auctions: Theory and Evidence Concerning Different Rules for Ending an Auction, July 2003

993 Pierre Salmon, The Assignment of Powers in an Open-ended European Union, July 2003

994 Louis N. Christofides and Chen Peng, Contract Duration and Indexation in a Period of Real and Nominal Uncertainty, July 2003

995 M. Hashem Pesaran, Til Schuermann, Björn-Jakob Treutler, and Scott M. Weiner, Macroeconomic Dynamics and Credit Risk: A Global Perspective, July 2003

996 Massimo Bordignon and Sandro Brusco, On Enhanced Cooperation, July 2003 
997 David F. Bradford, Addressing the Transfer-Pricing Problem in an Origin-Basis X Tax, July 2003

998 Daniel Gros, Who Needs Foreign Banks?, July 2003

999 Wolfram Merzyn and Heinrich W. Ursprung, Voter Support for Privatizing Education: Evidence on Self-Interest and Ideology, July 2003

1000 Jo Thori Lind, Fractionalization and the Size of Government, July 2003

1001 Daniel Friedman and Donald Wittman, Litigation with Symmetric Bargaining and TwoSided Incomplete Information, July 2003

1002 Matthew Clarke and Sardar M. N. Islam, Health Adjusted GDP (HAGDP) Measures of the Relationship Between Economic Growth, Health Outcomes and Social Welfare, July 2003

1003 Volker Grossmann, Contest for Attention in a Quality-Ladder Model of Endogenous Growth, August 2003

1004 Marcel Gérard and Joan Martens Weiner, Cross-Border Loss Offset and Formulary Apportionment: How do they affect multijurisdictional firm investment spending and interjurisdictional tax competition?, August 2003

1005 Burkhard Heer, Nonsuperneutrality of Money in the Sidrauski Model with Heterogeous Agents, August 2003

1006 V. Anton Muscatelli, Piergiovanna Natale, and Patrizio Tirelli, A Simple and Flexible Alternative to the Stability and Growth Pact Deficit Ceilings. Is it at hand?, August 2003

1007 Reto Foellmi and Josef Zweimüller, Inequality and Economic Growth: European Versus U.S. Experiences, August 2003

1008 James S. Costain and Michael Reiter, Business Cycles, Unemployment Insurance, and the Calibration of Matching Models, August 2003

1009 Marco Runkel, Optimal Contest Design when the Designer's Payoff Depends on Competitive Balance, August 2003

1010 Donald O. Parsons, Torben Tranaes and Helene Bie Lilleør, Voluntary Public Unemployment Insurance, August 2003

1011 Rüdiger Pethig and Andreas Wagener, Profit Tax Competition and Formula Apportionment, August 2003

1012 Johan Willner, Privatisation and Public Ownership in Finland, August 2003 